\title{
PENGEMBANGAN PERANGKAT PEMBELAJARAN KIMIA ANALITIK MATERI KROMATOGRAFI BERORIENTASI INKUIRI TERBIMBING
}

\author{
Dedeh Kurniasih $^{1}$, Hanum Mukti Rahayu ${ }^{2}$ \\ ${ }^{1}$ Pendidikan Kimia, Universitas Muhammadiyah Pontianak, Jl.A.Yani No.111, \\ Pontianak \\ ${ }^{2}$ Pendidikan Biologi, Universitas Muhammadiyah Pontianak, Jl.A.Yani No.111, \\ Pontianak \\ E-mail: dedeh.kurnia9@gmail.com
}

\begin{abstract}
The purpose of this research is to develop valid, practical, and effective guided inquiry teaching set to improve the students' achievement on the course of Analytical Chemistry in Muhammadiyah University. The researcher applied Thiagarajan 3-D model; define, design, and develop. The sample of this research was obtained by purposive sampling resulted in 7 students as the try out sample and 16 students as the main test sample. The data was collected by measurement, and indirect observation. The instruments of this research were pre-test and post-test questions, observation sheets, and questionnaire sheets. The findings of this research showed that the validity of the teaching set was given the score 1,00 by expert; the practicality of the teaching set from the students' responses was given the score 75,60 and 82,46; the students' achievement after utilizing the guided inquiry based teaching set showed that $81,25 \%$ fulfill the criteria of completeness. For that reason, the guided inquiry based teaching set developed in this research is suitable to be used in the teaching and learning process.
\end{abstract}

Keywords: Guided inquiry, chromatography, the development of a teaching set

Ilmu kimia merupakan produk (pengetahuan kimia yang berupa fakta, teori, prinsip dan hukum) temuan sains dan proses (kerja ilmiah). Pengembangan keterampilan berpikir menjadi hal yang penting di dalam pembelajaran ilmu kimia. Salah satu bidang ilmu kimia yang menjadi matakuliah di Program Studi Pendidikan Kimia di Universitas
Muhammadiyah Pontianak adalah Kimia Analitik.

Dalam penyampaiannya mata kuliah ini memuat tentang analisis secara kualitatif dan kuantitatif serta metode pemisahan. Oleh karena itu mahasiswa dituntut untuk dapat berpikir kritis, logis, kreatif, dan inovatif terhadap permasalahan yang dihadapi. Namun fakta di lapangan menunjukkan mahasiswa masih 
kesulitan dalam hal tersebut. Menurut Zubaidah (2010), sistem pendidikan lebih menekankan pada penyampaian informasi dari pada pengembangan kemampuan berpikir.

Hasil observasi dalam proses perkuliahan kimia analitik di program studi Pendidikan Kimia Universitas Muhammadiyah menunjukkan

Pontianak mahasiswa yang aktif dalam perkuliahan masing sangat kurang. Proses pembelajaran berlangsung dalam satu arah, yaitu proses pembelajaran yang mengacu pada proses transfer pengetahuan dari dosen ke mahasiswa (teacher centered). Akibatnya perkuliahan menjadi kurang menarik dan monoton. Hasil belajar mahasiswa untuk mata kuliah kimia analitik juga masih perlu dikatrol beberapa kali sebelum akhirnya dinyatakan memenuhi kriteria ketuntasan minimal yang telah ditetapkan dosen pengampu yaitu 70. Hal ini menunjukkan bahwa proses mahasiswa memperoleh pengetahuan adalah sesuatu hal yang sangat penting untuk dapat mencapai hasil belajar yang diharapkan. Penguasaan konsep pada mata kuliah Kimia Analitik menjadi dasar dan pendukung dalam memahami dan melakukan kerja ilmiah dalam mata kuliah keahlian kimia yang lain.

Wawancara terhadap enam mahasiswa dengan kemampuan atas, sedang, dan bawah semester III Program Studi Pendidikan Kimia Fakultas Keguruan dan Ilmu Pendidikan Universitas Muhammadiyah Pontianak menunjukkan bahwa tiga orang diantaranya mengalami kesulitan dalam memahami materi dalam mata kuliah Kimia Analitik dan lebih sering menunggu informasi dari dosen dibanding mencari dari sumber lain. Hasil wawancara ini menunjukkan bahwa kebiasaan selalu mendapatkan pengetahuan tanpa proses pencarian sendiri mengakibatkan pengetahuan tersebut akan lebih cepat menguap. Mahasiswa cenderung menunggu informasi diberikan oleh dosen dibanding mencari. Pembelajaran seperti itu mengakibatkan kemampuan berpikir tingkat tinggi siswa relatif rendah dikarenakan proses berpikirnya hanya ditekankan oleh bagaimana menyelesaikan persoalan yang terbatas.

Proses pembelajaran akan lebih efektif apabila mahasiswa secara aktif berpartisipasi dalam proses pembelajaran. Pemahaman akan lebih bertahan lama jika mahasiswa memperoleh pengetahuan dengan cara mencari sendiri dibanding yang diberikan secara langsung oleh dosen. Dengan demikian, mahasiswa akan mengalami, menghayati, dan menarik pelajaran dari pengalamanya. Pada akhirnya hasil belajar akan merupakan bagian dari pemikiran dan pengalamannya. Hasil pengalaman belajar akan lebih tertanam dalam pikiran dan kondisi demikian menuntut mahasiswa untuk lebih berpikir kreatif. Untuk mencapai keberhasilan pembelajaran yang diharapkan, upaya yang dapat dilakukan dosen adalah dengan cara memilih suatu model pembelajaran yang tepat dan inovatif dimana pembelajaran berpusat pada siswa (student centered learning). Salah satu model yang tepat dalam mata 
kuliah Kimia Analitik adalah inkuiri terbimbing (guided inquiry).

Sintak model pembelajaran inkuiri secara umum adalah : orientasi, merumuskan masalah, merumuskan hipotesis, mengumpulkan data, menguji hipotesis, dan merumuskan kesimpulan (Sanjaya, 2009). Mengacu pada sintak tersebut, pada pembelajaran inkuiri terbimbing dosen menyediakan bahan-bahan dan masalah untuk diselidiki atau ditelaah oleh mahasiswa untuk kemudian disusun prosedur pemecahan masalah tersebut. Melalui kegiatan ini mahasiswa diberi kesempatan untuk memiliki pengalaman belajar yang nyata dan aktif serta dilatih bagaimana memecahkan masalah sekaligus membuat suatu keputusan.

Sebelum model pembelajaran ini diterapkan maka perangkat pembelajaran perlu dibuat sedemikian rupa agar mengakomodir kelebihankelebihan yang ada dalam model inkuiri terbimbing ini. Pengkajian terhadap perangkat pembelajaran pada mata kuliah kimia analitik yang selama ini digunakan di Program Studi Pendidikan Kimia Universitas Muhammadiyah Pontianak menggiring peneliti untuk dapat mengembangkan perangkat yang berorientasi model inkuiri. Hal ini diharapkan dapat menumbuhkan kemampuan dalam berpikir secara ilmiah yang pada akhirnya meningkatkan hasil belajar mahasiswa.

\section{METODE}

Metode yang digunakan dalam penelitian pengembangan perangkat pembelajaran berorientasi inkuiri terbimbing ini yaitu metode penelitian dan pengembangan, (research and development) sesuai rancangan pengembangan model 4D oleh Thiagarajan, dkk. (Ibrahim, dkk., 2000; Mulyatiningsih, 2012: 195) yang terdiri atas tahap (1)

Pendefinisian (Define).

Perancangan (Design), dan (3) Pengembangan (Develop). Namun, pada tahap (4) Penyebaran (Disseminate) tidak dilakukan pada penelitian ini.

Populasi dalam penelitian ini adalah mahasiswa Program Studi Pendidikan Kimia Fakultas Keguruan dan Ilmu Pendidikan Universitas Muhammadiyah Pontianak yang telah mengambil mata kuliah Praktikum Kimia Analitik sebanyak 32 orang. Sampel penelitian adalah mahasiswa Program Studi Pendidikan Kimia yang mengambil mata kuliah Kimia Analitik. Sampel terdiri dari dua jenis, yaitu sampel uji coba awal (mahasiswa Program Studi Pendidikan Kimia Universitas Muhammadiayah Pontianak yang telah menerima mata kuliah Kimia Analitik sebanyak 7 orang, dan sampel utama yaitu mahasiswa Program Studi Pendidikan Kimia Universitas Muhammadiayah Pontianak yang akan mengambil mata kuliah ini sebanyak 16 orang. Sampel pada uji coba awal dipilih secara purposif berdasarkan kelompok strata kemampuan dasar akademik mahasiswa yang dilihat dari indeks prestasi kumulatif (IPK) rendah, sedang dan tinggi.

Adapun teknik dan alat pengumpulan data dalam penelitian ini adalah :1) teknik observasi langsung untuk mengetahui keterlaksanaan pembelajaran berorientasi inkuiri terbimbing 
menggunakan lembar observasi, 2) teknik komunikasi tidak langsung yang digunakan untuk mengetahui tingkat kepraktisan penggunaan perangkat pembelajaran berbasis inkuiri terbimbing menggunakan angket berskala Likert dengan jumlah 4 pilihan jawaban yaitu sangat setuju (SS), setuju (S), kurang setuju (KS), dan tidak setuju (TS) (Widoyoko, 2014 :155), 3) teknik pengukuran untuk mengetahui keefektifan perangkat pembelajaran berorientasi inkuiri terbimbing menggunakan soal pretest dan posttest dengan bentuk soal essay.

Prosedur yang dilakukan dalam penelitian ini terdiri atas 3 tahap yaitu (1) Tahap pendefenisian (define) yaitu penetapan tujuan pembelajaranyang terdapat dalam kurikulum dengan melakukan analisis kurikulum, analisis konsep, analisis siswa, dan analisis kondisi; (2) Tahap perencanaan (design) yang diawali dengan penyusunan perangkat pembelajaran meliputi silabus, rencana perkuliahan yang termuat dalam SAP (satuan administrasi perkuliahan) dan bahan ajar tentang kimia analitik materi kromatografi bagi mahasiswa dan lembar kerja mahasiswa (LKM) berisi tentang soal-soal latihan yang harus dikerjakan oleh mahasiswa dan dilanjutkan dengan pemilihan format bahan ajar (3) Tahap pengembangan (develop) yaitu tahapan mevalidasi dan menelaah bahan ajar yang telah dihasilkan. Nieveen (dalam Hobri, 2010:27) menetapkan bahwa kriteria pengembangan perangkat pembelajaran mencakup tiga hal, yaitu kevalidan (validity), kepraktisan (practically), dan keefektifan (effectiveness).
Perangkat pembelajaran divalidasi menggunakan validasi isi menurut Gregory (Hairida \& Astuti, 2012: 29). Untuk mengetahui apakah instrumen itu valid atau tidak harus dilakukan melalui penelaahan kisikisi instrumen untuk memastikan bahwa instrumen yang seharusnya dikuasai secara proporsional (Djaali \& Muljono, 2007: 50).

Analisis kevalidan perangkat pembelajaran berorientasi inkuiri terbimbing dalam penelitian ini meliputi beberapa aspek, yaitu tampilan, isi, dan bahasa. Hasil validitas kemudian dicocokkan dengan kriteria kevalidan perangkat dan instrumen penelitian yang dapat dilihat pada Tabel 1. Perangkat pembelajaran dikatakan valid jika telah memenuhi kriteria kevalidan minimal 0,6.

Tabel 1. Kriteria kevalidan perangkat dan instrumen penelitian

\begin{tabular}{cc}
\hline Nilai & Kriteria \\
\hline $0,80-1,00$ & Sangat tinggi \\
$0,60-0,79$ & Tinggi \\
$0,40-0,59$ & Sedang \\
$0,20-0,39$ & Rendah \\
$0,00-0,19$ & Sangat rendah \\
\hline
\end{tabular}

Setelah perangkat pembelajaran dinyatakan valid selanjutnya akan diujicobakan untuk mengetahui kepraktisan dan keefektifannya dalam proses pembelajaran kimia analitik.

Pelaksanaan uji coba mengimplementasikan rancangan One Group Pretest-Postest Design (Tuckman, 1978) dengan pola sebagai berikut:

\section{$01 \times 02$}

O1 adalah uji awal, bertujuan untuk mengukur kemampuan belajar 
mahasiswa sebelum pembelajaran berlangsung, $\mathrm{X}$ adalah proses belajar mengajar yang berorientasi pada inkuiri terbimbing sedangkan $\mathrm{O} 2$ adalah uji akhir yang bertujuan untuk mengukur kemampuan belajar siswa setelah pembelajaran berlangsung.

Analisis

kepraktisan perangkat pembelajaran ditunjukkan dengan nilai respon mahasiswa terhadap seluruh pernyataan rata-rata mendapatkan nilai $>70$. Perangkat pembelajaran berorientasi inkuiri terbimbing yang dikembangkan dikatakan efektif jika setelah mengikuti pembelajaran mahasiswa tuntas secara klasikal atau lebih besar sama dengan $65 \%$ dari jumlah siswa yang ada di kelas tersebut.

\section{HASIL DAN PEMBAHASAN}

\section{Tahap Pendefinisian (Define)}

Tahap dalam pendefinisian adalah peneliti melakukan analisis kebutuhan (need assessment). Hal yang dilakukan pertama kali adalah studi lapangan. Studi ini dilakukan dengan mewancarai enam orang mahasiswa semester VI. Hasil wawancara menunjukkan informasi bahwa pembelajaran masih menggunakan metode ceramah dengan diselingi diskusi. Pembelajaran menjadi kurang efektif karena mahasiswa cenderung menunggu informasi dari dosen saja. Hal ini menyebabkan mahasiswa menjadi pasif sehingga mahasiswa tidak terfokus pada materi yang disampaikan.

Analisis kebutuhan juga meninjau silabus Perkuliahan Kimia Analitik II yang menjadi acuan pelaksanaan kegiatan pembelajaran. Dalam silabus, mahasiswa dituntut mencapai tujuan pembelajaran yang telah ditetapkan. Setelah perkuliahan ini mahasiswa diharapkan dapat mendefinisikan prinsip dasar kromatografi kertas, kromatografi lapis tipis, dan kromatografi kolom serta dapat menyebutkan kegunaan kromatografi bagi kehidupan manusia. Hasil dari perumusan tujuan pembelajaran yang dilakukan ini menjadi pedoman pengembangan perangkat pembelajaran berorientasi inkuiri terbimbing.

Pemahaman setiap mahasiswa dalam materi kromatografi tidak sama dengan mahasiswa yang lainnya. Hal ini menyebabkan perbedaan pendapat antara mahasiswa tentang definisi prinsip dasar kromatografi kertas, kromatografi lapis tipis dan kromatografi kolom serta kegunaan kromatografi bagi kehidupan manusia.

\section{Tahap Perancangan (Design)}

Hal yang dilakukan pada tahap ini adalah merancang prototype perangkat pembelajaran meliputi penyusunan tes kriteria, pemilihan media, pemilihan format dan membuat desain awal perangkat pembelajaran. Penyusunan tes merupakan langkah yang menghubungkan antara tahap pendefinisian (define) dengan tahap perancangan (design) yaitu menyusun tes hasil belajar. Tes ini digunakan untuk menentukan keefektifan dari perangkat pembelajaran yang dikembangkan.

Desain awal (prototype) perangkat pembelajaran dibuat berdasarkan storyboard yang telah ada. Desain awal ini merupakan desain yang akan divalidasi oleh para validator untuk mengetahui kekurangan serta perbaikan yang 
harus dilakukan sebelum perangkat pembelajaran di uji coba.

\section{Tahap Pengembangan (Develop)}

Tahap pengembangan adalah tahap untuk menghasilkan produk pengembangan. Produk pengembangan yang akan dihasilkan berupa perangkat pembelajaran pada materi kromatografi. Perangkat pembelajaran yang dikembangkan memodifikasi model pengembangan 4-D (four D model). Validasi ahli merupakan kegiatan yang dilakukan untuk mereview dan melihat aspek kevalidan perangkat pembelajaran yang dikembangkan. Desain awal (prototype) perangkat pembelajaran yang telah dibuat kemudian divalidasi oleh ahli untuk melihat tingkat kelayakan produk awal sekaligus memberikan saran-saran untuk perbaikan. Kevalidan perangkat pembelajaran diperoleh berdasarkan hasil penilaian para ahli yang terdiri atas 2 orang dosen. Kevalidan perangkat pembelajaran terdiri atas penilaian terhadap aspek aspek format, isi dan bahasa menggunakan lembar validasi perangkat pembelajaran.

\section{Analisis Kevalidan}

Kevalidan

perangkat

pembelajaran berorientasi inkuiri terbimbing diketahui berdasarkan penilaian dua orang validator. Seperti pendapat Widodo \& Jasmadi (2008: 57) yang menyatakan bahwa bahan ajar yang baik harus memenuhi syarat didaktik, konstruksi dan teknis. Maka acuan penilaian kevalidan pada penelitian ini memenuhi syarat didaktik yakni mampu mengikuti asas-asas belajar yang efektif ditinjau dari kesesuaian judul, tujuan pembelajaran, kompetensi dasar, kebenaran konsep, kejelasan langkah dan kelengkapan komponen. Syarat konstruksi yakni penggunaan bahasa, susunan kalimat, kesantunan bahasa serta makna kalimat. Syarat teknis yakni berkaitan dengan kejelasan tulisan dan gambar, pemilihan jenis huruf dan angka serta kemenarikan tampilan.

Validator menyatakan bahwa perangkat pembelajaran berorientasi inkuiri terbimbing layak digunakan setelah dilakukan revisi sesuai saran/perbaikan dari kedua validator (V1 dan V2). Hasil rekapitulasi validasi dapat dilihat pada Tabel 2 .

Tabel 2. Rekapitulasi validasi ahli materi

\begin{tabular}{|c|c|c|c|}
\hline \multirow{2}{*}{ No } & \multirow{2}{*}{ Aspek Penilaian } & \multicolumn{2}{|c|}{ Skor } \\
\hline & & V1 & $\mathbf{V 2}$ \\
\hline \multicolumn{4}{|c|}{ Materi } \\
\hline 1. & Kesesuaian judul & 4 & 3 \\
\hline 2. & $\begin{array}{l}\text { Kesesuaian isi perangkat pembelajaran dengan tujuan } \\
\text { pembelajaran dan Kompetensi Dasar }\end{array}$ & 4 & 4 \\
\hline 3. & Kebenaran konsep materi ditinjau dari aspek keilmuan & 4 & 4 \\
\hline 4. & Kesesuaian dengan tingkat kematangan berpikir peserta didik & 3 & 4 \\
\hline 5. & Kesesuaian dengan tahapan inkuiri terbimbing & 4 & 4 \\
\hline 6. & Kejelasan langkah kerja & 4 & 3 \\
\hline & Kelengkapan komponen & 4 & 4 \\
\hline \multicolumn{2}{|c|}{ Koefisien Validitas } & 1,00 & \\
\hline \multicolumn{4}{|c|}{ Media } \\
\hline 1. & Keteraturan desain & 3 & 4 \\
\hline
\end{tabular}




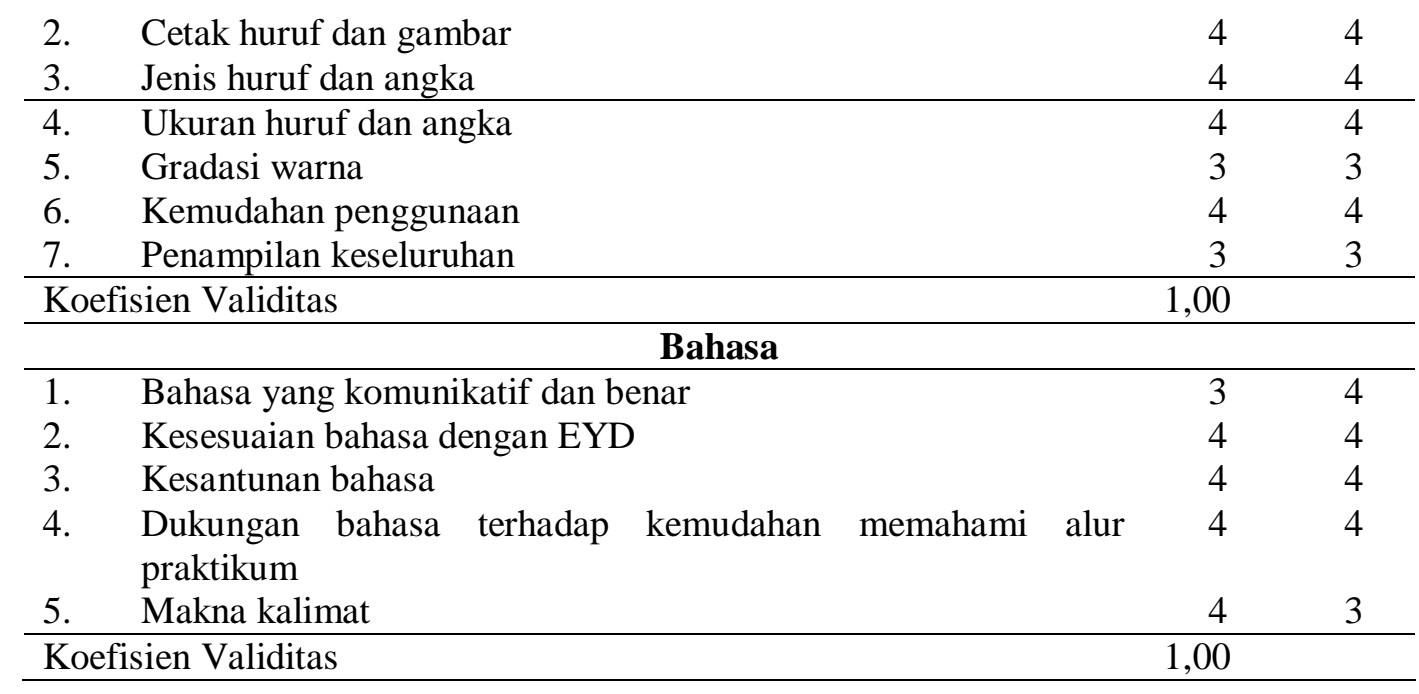

Dari Tabel 2 diketahui bahwa pada aspek materi, skor yang diberikan oleh validator adalah 4 untuk sebagian besar aspek penilaian, namun pada indikator kesesuaian materi pada tingkat kematangan berpikir mahasiswa mendapatkan skor 3. Validator 2 juga memberikan skor 4 pada sebagian besar aspek penilaian, namun untuk aspek kesesuaian judul dan kejelasan langkah kerja mendapatkan skor 3. Hasil akhir analisis penilaian ahli materi menunjukkan nilai koefisien validitas sebesar 1,00. Sesuai dengan kriteria kevalidan menurut Gregory, maka nilai tersebut berada pada kriteria sangat tinggi.

Pada aspek media, kedua validator memberikan skor 3 untuk gradasi warna dan penampilan keseluruhan. Dari keteraturan desain mendapatkan skor 3 dari validator 1 . Aspek penilaian lainnya mendapatkan skor 4 dari kedua validator. Hasil akhir analisis penilaian dari segi media memiliki nilai koefisien validitas sebesar 1,00. Sesuai dengan kriteria kevalidan menurut Gregory, maka nilai tersebut berada pada kriteria sangat tinggi.
Tabel 2 menunjukkan bahwa kedua validator memberikan skor 4 pada sebagian besar pada aspek bahasa. Namun, validator 1 memberikan skor 3 pada aspek bahasa yang komunikatif dan benar. Hasil akhir analisis penilaian ahli bahasa diperoleh koefisien validitas sebesar 1,00. Sesuai dengan kriteria kevalidan menurut Gregory, maka nilai tersebut berada pada kriteria sangat tinggi.

Secara umum perangkat pembelajaran berorientasi inkuiri terbimbing yang dikembangkan telah memiliki validitas dengan kriteria sangat tinggi. Perangkat pembelajaran sebagai salah satu bahan ajar yang digunakan siswa dalam proses belajar mengajar haruslah memiliki validitas yang baik agar tujuan pembelajaran dapat tercapai dengan hasil efektif. Hal ini sesuai dengan pendapat Yasir, dkk., (2013) yang menyatakan bahwa bahan ajar yang valid dapat diterapkan dalam pembelajaran dengan hasil keterlaksanaan pembelajaran dalam kategori baik, sehingga dapat mencapai indikator pembelajaran. 


\section{Analisis Kepraktisan}

Aspek kepraktisan dapat diketahui dari analisis angket mahasiswa terhadap penggunaan perangkat pembelajaran berorientasi inukiri terbimbing. Angket ini meliputi tanggapan terhadap penggunaan, materi, tampilan, bahasa, tulisan, bahan diskusi, serta perintah pada perangkat pembelajaran berorientasi inkuiri terbimbing. Angket diberikan sebanyak dua kali yaitu setelah melakukan uji coba lapangan awal dan setelah melakukan uji coba lapangan utama.

Adapun analisis respon mahasiswa setelah dilakukan dua kali uji coba menunjukkan respon terhadap seluruh pernyataan rata-rata mendapatkan nilai $>70$. Hal ini berarti aspek materi, tampilan, bahasa, tulisan, bahan diskusi, penggunaan serta perintah pada perangkat pembelajaran berdasarkan respon mahasiswa telah sesuai untuk digunakan dalam pembelajaran materi kromatografi. Adapun rekapitulasi hasil analisis angket respon mahasiswa dapat dilihat pada Tabel 3.

Tabel 3. Rekapitulasi hasil angket respon mahasiswa

\begin{tabular}{cc}
\hline Uji coba & Nilai \\
\hline Awal & 75,60 \\
Utama & 82,46 \\
\hline
\end{tabular}

Tabel 3 menunjukkan terjadi peningkatan nilai respon mahasiswa. Nilai respon mahasiswa setelah dua kali uji coba meningkat sebesar 6,86. Secara umum terjadi peningkatan respon dari uji coba lapangan awal dan uji coba lapangan utama, sehingga dapat disimpulkan bahwa perangkat pembelajaran berorientasi inkuiri terbimbing yang dikembangkan telah memenuhi aspek kepraktisan dengan tingkat kepraktisan baik.

\section{Analisis Keefektifan}

Keefektifan perangkat pembelajaran berbasis inkuiri terbimbing dapat diketahui dari hasil belajar setelah pembelajaran. Perangkat pembelajaran berorientaasi inkuiri terbimbing yang dikembangkan dikatakan efektif jika mahasiswa tuntas secara klasikal atau lebih besar sama dengan $65 \%$ dari jumlah mahasiswa yang ada di kelas tersebut setelah mengikuti pembelajaran menggunakan perangkat pembelajaran berorientasi inkuiri terbimbing (Astuti, dkk., 2012: 54). Analisis keefektifan dilakukan dengan menganalisis nilai sebelum dan sesudah pembelajaran menggunakan perangkat pembelajaran berorientasi inkuiri pada mahasiswa yang dijadikan sampel uji coba lapangan utama. Hasil pretest dan posttest mahasiswa ditunjukkan seperti pada Tabel 4.

Tabel 4. Rekapitulasi hasil pretest dan posttest mahasiswa

\begin{tabular}{lll}
\hline & Pre-test & Post-test \\
\hline Nilai Rata-Rata & 51,44 & 75,75 \\
\hline \% Ketuntasan & $18,75 \%$ & $81,25 \%$ \\
\hline
\end{tabular}

Tabel 4 menunjukkan persentase ketuntasan mahasiswa pada pretest hanya sebesar $18,75 \%$ sedangkan persentase ketuntasan posttest siswa sebesar $81,25 \%$. Data tersebut menunjukkan bahwa terjadi peningkatan persentase ketuntasan mahasiswa sebesar $62,5 \%$ sehingga dapat disimpulkan bahwa perangkat pembelajaran berbasis inkuiri 
terbimbing yang dikembangkan telah memenuhi aspek keefektifan.

Pengembangan perangkat pembelajaran berbasis inkuiri terbimbing yang telah melewati uji kevalidan, kepraktisan dan keefektifan telah layak digunakan dalam pembelajaran. Selain memiliki tampilan cukup menarik, perangkat pembelajaran berbasis inkuiri juga terdapat arahan yang memfasilitasi mahasiswa melakukan aktivitas merumuskan masalah, kemudian mencari, menyelidiki, dan menemukan sendiri jawaban dari suatu masalah yang dipertanyakan.

Dalam pembelajaran inkuiri terbimbing, mahasiswa diberikan pengalaman dalam membangun pengetahuan. Pengalaman dalam belajar dapat mempermudah siswa dalam memahami dan mengingat meteri yang sedang dipelajari, karena siswa akan lebih menghayati proses atau kegiatan yang sedang dilakukan (Sudesti, dkk., 2014: 1). Pemberian contoh nyata yang diambil dari beberapa artikel terbaru juga memberikan wawasan kepada mahasiswa tentang bagaimana pengaplikasian metode kromatografi dalam kehidupan sehari-hari. Hal ini memberikan pengalaman ilmiah dan makna yang berarti bagi mahasiswa.

\section{SIMPULAN DAN SARAN}

Perangkat pembelajaran berbasis inkuiri terbimbing yang dikembangkan pada penelitian ini telah layak digunakan sebagai bahan ajar dalam materi kromatografi pada mata kuliah Kimia Analitik II karena telah memenuhi kriteria kevalidan, kepraktisan dan keefektifan sebagai berikut:
1. Hasil analisis kevalidan menunjukkan nilai koefisien validitas sebesar 1,00 dengan kriteria sangat tinggi.

2. Hasil analisis kepraktisan berdasarkan nilai respon mahasiswa pada uji coba lapangan awal dan utama berturut-turut adalah 75,60 dan 82,46 .

3. Hasil analisis keefektifan, yang didasarkan pada analisis hasil belajar setelah menggunakan perangkat pembelajaran berbasis inkuiri terbimbing menunjukkan $81,25 \%$ mahasiswa telah memenuhi kriteria ketuntasan minimal.

\section{DAFTAR PUSTAKA}

Astuti, W. P., Nur, M., \& Rahayu, Y. R. (2012). Pengembangan Perangkat Pembelajaran Untuk Meningkatkan Hasil Belajar Siswa Melalui Pelatihan Strategi Belajar Membaca pada Pokok Bahasan Sistem Pencernaan Darah di SMA. Pendidikan Sains Pascasarjana Universitas Negeri Surabaya, Vol. 1, No. 1, 52-59.

Djaali, \& Muljono, P. (2007). Pengukuran dalam Bidang Pendidikan. Jakarta: Grasindo.

Hairida, \& Astuti, M. W. (2012). Self Efficacy dan Prestasi Belajar Siswa dalam Pembelajaran IPA-Kimia. Jurnal Pendidikan Matematika dan IPA, Vol. 3, No. 1, 29-33.

Hobri. (2010). Metodologi Penelitian Pengembangan

(Aplikasi 
40 Jurnal Pendidikan Matematika dan IPA Vol. 8 No. 2 Juli 2017: 31-40

Pada Penelitian Pendidikan Matematika). Jember: Pena Salsabila

Ibrahim, M., Rachmadiarti, F., Nur, M., \& Ismono. (2000). Pembelajaran Kooperatif. Surabaya: UNESA University Press.

Mulyatiningsih, E. (2012). Metode Penelitian Terapan Bidang Pendidikan. Bandung: Alfabeta.

Sanjaya, W. (2009). Strategi Pembelajaran Berorientasi Standar Proses Pendidikan. Jakarta: Kencana Prenada Media Group.

Sudesti, R., Sudargo, F., \& Nurjhani, M. K. (2014). Penerapan Pembelajaran Berbasis Praktikum Untuk Meningkatkan Penguasaan Konsep dan Keterampilan Proses Sains Siswa SMP pada Subkonsep Difusi Osmosis. Formica Education Online, Vol. 1, No. 1.

Tuckman, B.W. (1978). Conducting Educational Research. Second Edition. United States of America: Harcourt Brace Jovanovich, Inc.

Widodo, C. S., \& Jasmadi. (2008). Panduan Menyusun Bahan Ajar Berbasis Kompetensi. Jakarta: Alex Media Komputindo.

Widoyoko, E. P. (2014). Penilaian Hasil Pembelajaran di
Sekolah. Yogyakarta: Pustaka Pelajar.

Yasir, M., Susanti, E., \& Isnawati. (2013). Pengembangan Lembar Kerja Siswa (LKS) Berbasis Strategi Metakognitif Untun Meningkatkan Hasil Belajar Siswa pada Materi Pewarisan Sifat. BioEdu, Vol. 2, No. 1, 77-83.

Zubaidah, S. (2010). Berpikir Kritis: Kemampuan Berpikir Tingkat Tinggi yang Dapat Dikembangkan melalui Pembelajaran Sains. Makalah Seminar Nasional Sains. Universitas Negeri Surabaya. 